\title{
Exploring the Correlation of Students' Vocabulary Mastery and Reading Comprehension at the Second grade of SMP Negeri 1 Kolaka
}

\author{
Bimas Reskiawan \\ bimasreskiawan@gmail.com \\ Hariadi Syam \\ adhysyam88@gmail.com \\ Universitas Sembilan Belas November
}

\begin{abstract}
The aim of this research was to find out the correlation between the students' vocabulary mastery and the students' reading comprehension at the second Grade of SMPN 1Kolaka. The population of this research was all the second grade students of SMP Negeri 1 Kolaka which consist of 206 students. The sample of this research is 26 students, it is class VIII B. The instruments in this research were two kinds of test, they were vocabulary test and reading comprehension test, each test consisted of 20 multiple choice. All the data gained in this research was analyzed by using the formulation of Pearson Product Moment Correlation Coefficient. According to the result of the analysis and statistical calculate, it found that $\mathrm{r}_{\mathrm{xy}}$ was 0.705 and $\mathrm{r} t$ was 0.404 with the degree of freedom $(\mathrm{df}=\mathrm{N}-\mathrm{nr})$ was 24 . By comparing the values of $\mathrm{r} x y$ and $\mathrm{r} t$, the result was $\mathrm{r} x y$ was bigger than $\mathrm{r} t$, in other words $\mathrm{rcount}$ was higher than $r$ table. It means that there was correlation between students' vocabulary mastery and reading comprehension and coefficient correlation was high, in this case the alternative hypothesis is accepted. Based on the finding from this research, it could be concluded that vocabulary mastery helps the students to comprehend the text. To solve the problem in comprehending the text in which students should have sufficient vocabulary that can help them in doing their in reading test.
\end{abstract}

Keyword : Correlation, Vocabulary, Reading Comprehension

\section{INTRODUCTION}

According to Byrne (1988), writing is an activity to produce a sequence of sentences arranged in a particular order and linked together in certain ways. Writing can be defined as a communicative act, a way of sharing observation, information, thoughts, or ideas with our selves and other. In addition, Harmer (1998) states that the reasons for teaching writing to students of English as a foreign language are for reinforcement, language development, learning style, and most importantly, writing is as a basic skill. 
Vocabulary mastery is important because it is one of element that linked the four skills such as reading, listening, writing and speaking. Without vocabulary there is nothing we can say. Wilkins (2002) expressed that, despite having good skills and grammar, the ability will be futile if it does not have enough mastery of vocabulary. In addition, Vocabulary is the component of the English language which holds an important role in communication (Hart and Risley, 2003). It means that we must master the vocabulary, if the students have more vocabularies, then they will develop the four language skills. Especially, Reading skill.

Smith (2005) who stated that reading is a process that builds the understanding of the essence in writing text. It means that reading is an interactive activity to reap the meaning of contain in writing. Supriyono (2005) said that the important of reading is as a means of getting information and training in reading comprehension to improve our development. Reading is receptive skill of receiving information through written language. In process of accepting is the most important is the understanding of information conveyed through written language.

Furthermore, the students are expected to have sufficient vocabulary especially for students who learn English as foreign language. Vocabulary plays a significant role in comprehending reading text. To be success in reading students need to master of many kinds of vocabulary which enable them to understand the text. Armbruster (2002) confessed that knowledge of the meaning of word is strongly related to reading comprehension process. The students are going to be easier in accepting English text when they have many vocabularies. By having large extent of vocabulary, a learner will be easier to understanding the meaning from the text being read.

Based on the explanation above, this research was intended to answer the following question: "is there any significant correlation between the students' vocabulary mastery and the students' reading comprehension at the second Grade of SMPN 1 Kolaka?" the result of this research is expected to be taken as one of references for the educators to teach vocabulary and reading.

\section{LITERATURE OF REVIEW}

Reading comprehension is one of ability to understand the meaning in a passage through writing or reading, whether in the form of simple ideas, ideas detail, and all understanding. The ability to read a person's understanding is said to be good if he is able to capture or understand all the content contained in the reading (Arham \& Hudriati, 2018). This ability can be done well if the student is mastering the vocabulary well. From the above explanation, it can be said that students who master the vocabulary well then the ability to read the understanding is also good. Based on the theories, that has been described then there is suspected a positive relationship between students' vocabulary mastery with the ability to 
read comprehension. The higher vocabulary is the higher the ability to read comprehension. Thus, it is clear that a person has a large vocabulary or vocabulary and knowing exactly what the vocabulary means will understand the content of the passage well (Andry wicaksono, 2011).

Furthermore, Reading comprehension and vocabulary mastery have a solid relationship. This statement is in line with Sedita (2005), who states that vocabulary knowledge is crucial in reading comprehension and determining how well students are in comprehension the texts. In the concern to this problem, this research attempts to discover the ability of students' reading comprehension, students' vocabulary mastery and the correlation between students' reading comprehension and their vocabulary mastery.

\section{METHOD}

This study employed quantitative method which was used to test the hypothesis that had been set. Sugiyono (2012) that associative hypothesis is a temporary answer to the associative problem formulation that asks the relationship between two or more variables qualitative research.

This research was conducted at SMPN 1 Kolaka. It consists of eight classes, A to $\mathrm{H}$. The researcher chose class VIII B which consist of 26 students as a sample because it was recommended by the English teacher to be investigated since they considered that their students of this class have good English better than the other classes.

In this study, data were collected through objective test. The test was used by the researcher consists of two main tests. They were vocabulary mastery test and reading comprehension test, each test consists of 20 items. There were some procedures in this research process, they were:

1. Preparing the students' vocabulary mastery and reading comprehension test

2. The researcher did try out in the school to know the students' level. After that, the researcher calculated the data to get the result of validity and reliability of test.

3. The researcher conducted the study, the first week on Wednesday and Thursday, 9-10 ${ }^{\text {th }}$ May 2018, the researcher conducted discussion about reading comprehension test during two meetings.

4. In the second week on Wednesday, $16^{\text {th }}$ may 2018 , the researcher distributed the vocabulary test to the students.

5. In the last week on Wednesday, $23^{\text {td }}$ May 2018, the researcher distributed the reading comprehension test. It was doing to avoid negative things happen like the occurrence of stress and fatigue on students.

6. In the last, the researcher analyzed the data. 
The aim of analyzing data was to determine whether student's vocabulary mastery and reading comprehension have significant positive correlation or not by using descriptive statistic and inferential. Firstly, the researcher checked the completeness of the data then gave scoring the tests. Afterwards, the researcher processes the data by using Descriptive Statistic and Inferential.

\section{RESULT AND DISCUSSIONS}

\section{Analysis Descriptive Statistic Of Vocabulary Mastery}

Based on the data accounting of vocabulary, it could be seen in Appendix IX the researcher tried to calculated mean and SD of students' vocabulary mastery by using Microsoft excel.

Table 4.1 Descriptive Statistic of Vocabulary Mastery

\begin{tabular}{|c|c|c|}
\hline Students' score & Frequency & Percentage (\%) \\
\hline 40 & 1 & $3.8 \%$ \\
\hline 45 & 1 & $3.8 \%$ \\
\hline 55 & 1 & $3.8 \%$ \\
\hline 60 & 3 & $11.4 \%$ \\
\hline 65 & 6 & $22.8 \%$ \\
\hline 70 & 2 & $7.6 \%$ \\
\hline 80 & 2 & $7.6 \%$ \\
\hline 85 & 6 & $22.8 \%$ \\
\hline 90 & 4 & $15.2 \%$ \\
\hline Total & $\mathbf{2 6}$ & $\mathbf{1 0 0 \%}$ \\
\hline Mean & $\mathbf{3 2 . 3 0}$ \\
\hline Maximum & $\mathbf{9 0}$ \\
\hline Minimum & $\mathbf{4 0}$ \\
\hline SD & $\mathbf{1 4 . 4 5}$ \\
\hline
\end{tabular}

Based on the data, it was found that the mean score of vocabulary test of the second grade students of SMP Negeri 1 Kolaka was 72.30. It could be said that the vocabulary mastery is good as could be seen in Table 4.2 below. From the students final score of vocabulary mastery, then the score was classification into very poor, poor, fair, good, and very good (Arikunto, 2003) in provided in to the table below:

Table 4.2 Classification of Students Score of Vocabulary Mastery

\begin{tabular}{|c|c|c|c|c|}
\hline No & Classification & Interval score & Frequency & Percentage \\
\hline 1 & Very Poor & $00-39$ & 0 & 0 \\
\hline 2 & Poor & $40-55$ & 3 & $11.4 \%$ \\
\hline 3 & Fair & $56-65$ & 9 & $34.2 \%$ \\
\hline 4 & Good & $66-79$ & 2 & $7.6 \%$ \\
\hline 5 & Very Good & $80-100$ & 12 & $45.6 \%$ \\
\hline
\end{tabular}




\begin{tabular}{|c|c|c|c|}
\hline & Total & 26 & $100 \%$ \\
\hline
\end{tabular}

Table 4.2 showed that for very poor level it could be seen nobody ( $0 \%)$ who got categorized of 26 students, for poor level there were 3 students or $11.4 \%$ of 26 students. For fair level, it was indicated 9 students or $34.2 \%$ of 26 students, for good level there were 2 students or $7.6 \%$ of 26 students and 12 students or $45.6 \%$ who categorized of very good.

Based on the table above, there were 12 students or $45.6 \%$ who got categorized of very good. It means that, students' score of vocabulary mastery was categorized very good level, it was because number of students mostly got score around 80-100.

\section{Analysis Descriptive Statistic Of Reading Comprehension}

The result of reading comprehension test could be seen in the Appendix IX. Based on the data, the researcher tried to calculated mean and SD of students' reading comprehension by using Microsoft excel.

Table 4.3 Descriptive Statistic of Reading Comprehension

\begin{tabular}{|c|c|c|}
\hline Students' score & Frequency & Percentage (\%) \\
\hline 50 & 3 & $11.4 \%$ \\
\hline 55 & 2 & $7.6 \%$ \\
\hline 60 & 4 & $15.2 \%$ \\
\hline 65 & 2 & $7.6 \%$ \\
\hline 70 & 5 & $19 \%$ \\
\hline 75 & 5 & $11.4 \%$ \\
\hline 80 & 3 & $7.6 \%$ \\
\hline 85 & 2 & $\mathbf{1 0 0} \%$ \\
\hline Total & $\mathbf{2 6}$ & $\mathbf{3}$ \\
\hline Mean & $\mathbf{6 7 . 1 1}$ \\
\hline Maximum & $\mathbf{3 0}$ \\
\hline Minimum & $\mathbf{1 3 . 4 2}$ \\
\hline SD & \multicolumn{3}{|c|}{} \\
\hline
\end{tabular}

Based on the data was found that the mean score of reading test of the second grade students of SMP Negeri 1 Kolaka is 67.11. It could be said that the reading comprehension is good. From the students final score of reading comprehension, then the score was classification into very poor, poor, fair, good, and very good (Arikunto, 2003) in provided in to the table bellows:

Table 4.4 Classification of Students Score of Reading Comprehension

\begin{tabular}{|l|l|l|l|l|}
\hline No & Classification & Interval score & Frequency & Percentage \\
\hline
\end{tabular}




\begin{tabular}{|c|c|c|c|c|}
\hline 1 & Very Poor & $00-39$ & 0 & 0 \\
\hline 2 & Poor & $40-55$ & 5 & $19 \%$ \\
\hline 3 & Fair & $56-65$ & 6 & $22.8 \%$ \\
\hline 4 & Good & $66-79$ & 10 & $38 \%$ \\
\hline 5 & Very Good & $80-100$ & 4 & $15.2 \%$ \\
\hline & & $\mathbf{2 6}$ & $\mathbf{1 0 0} \%$ \\
\hline
\end{tabular}

Table 4.4 showed that for very poor level it could be seen nobody $(0 \%)$ who got categorized of 26 students, for poor level there were 5 students or $19 \%$ of 26 students. For fair level, it was indicated 6 students or $22.8 \%$ of 26 students, for good level there were 10 students or $38 \%$ of 26 students and 4 students or $15.2 \%$ who categorized of very good.

Based on the table above, there were 10 students or $38 \%$ who got categorized of good. It means that, students' score of reading comprehension was categorized very good level, it was because number of students mostly get score around 66-79.

\section{Inferential Statistic Analysis Correlation Between Vocabulary Mastery And Reading Comprehension}

The main goal of this research was to find out whether or not there was a significant correlation between vocabulary mastery and reading comprehension at the second grade students of SMP Negeri 1 Kolaka.

To find out the coefficient correlation between vocabulary mastery and reading comprehension of the second grade students of SMP Negeri 1 Kolaka, the researcher used Pearson product moment formula, it could be seen in Appendix X. Based on the data in appendix $\mathrm{X}$, the researcher found that:

$$
\begin{array}{lllll}
\sum \mathbf{X} & =1880 & \sum \mathbf{Y} & =1745 & \sum \mathbf{X Y}=128972 \\
\sum \mathbf{X}^{\mathbf{2}} & =141150 & \sum \mathbf{Y}^{\mathbf{2}} & =120125 &
\end{array}
$$

Where:

$$
\begin{aligned}
& \mathrm{X} \quad \text { = Data of Students' Vocabulary Mastery } \\
& \mathrm{Y} \quad \text { = Data of Students' Reading Comprehension }
\end{aligned}
$$

The result of analysis correlation between students' vocabulary mastery and reading comprehension by using product moment formula (see Appendix XI) showed that $r_{\text {count }}=0.705$, it was bigger than $r$ table with total participant 26 students and significant level 5\%. It showed the point 0.388 .

In answering the test none of students got 100 score. The high score was 90 in vocabulary test and 85 in reading test. While the lowest was 40 in vocabulary test and 50 in reading test. The result of the computation of the 
correlation between students' vocabulary mastery and reading comprehension at the second grade of SMP Negeri 1 Kolaka was 0.705. By used criteria for evaluation and interpretation of correlation coefficient by Sugiyono, 2012.

Table 4.5: Coefficient Interval and Relationship Level

\begin{tabular}{|l|c|}
\hline \multicolumn{1}{|c|}{ Coefficient interval } & Level of relationship \\
\hline $0,00-0,199$ & Correlation is very low \\
\hline $0,20-0,399$ & Low correlation \\
\hline $0,40-0,599$ & Medium correlation \\
\hline $0,60-0,799$ & Strong correlation \\
\hline $0,80-1,00$ & The correlation is very strong \\
\hline
\end{tabular}

Based on the table 4.5 it means that the correlation between the two variables was strong correlation, it was positive correlation because the value was 0.705 .

From the result of statistic calculation, it indicated that $\mathrm{r}_{\mathrm{xy}}$ was 0.705 with the degree of freedom $(d f=N-n r)$ is $26-2=24$,. Where:

$\mathrm{df}=$ degree of freedom

$\mathrm{nr}=$ number of variable $(\mathrm{X}$ and $\mathrm{Y})$

At the degree of significant of $5 \%=0.404$

In the table of significant of $5 \%$ and $1 \%$ and the value were 0.388 and 0.496. By comparing the value of $r_{x y}=0.705$ and $r t=0.388$. The researcher made an assumption of the hypothesis, that $\mathrm{r}_{\mathrm{xy}}$ is bigger that $\mathrm{rt}$.

The statistic hypothesis in this research they were:

H0: $\alpha=0, \mathrm{H} 0$ is accepted, there was no correlation.

$\mathrm{H} 1: \alpha \neq 0, \mathrm{H} 1$ is accepted, there was a positive correlation.

$\mathrm{H}_{2}: \alpha \neq 0, \mathrm{H}_{2}$ is accepted, there was a negative correlation

The result of hypothesis is $\alpha \neq 0$ or $\mathrm{r}_{\mathrm{xy}}$ is bigger that $\mathrm{rt}$ and the score of vocabulary and reading was straight comparable. So $\mathrm{H}_{0}$ and $\mathrm{H}_{2}$ is rejected and $\mathrm{H}_{1}$ is accepted. It means that there was a positive correlation between students' vocabulary mastery and reading comprehension at the second grade of SMP Negeri 1 kolaka in academic year 2017/2018. 
Based on the interpretation above, the researcher finally gain the valid answer from the question which was stated in the first chapter ( 1.2$)$ as problem of the research.

\section{Discussion}

Based on the result of testing hypothesis, the Null Hypothesis $\left(\mathrm{H}_{0}\right)$ which explained that there was no correlation between vocabulary mastery and reading comprehension was rejected, $\mathrm{H}_{2}$ which explained that there was negative correlation between vocabulary mastery and reading comprehension was rejected While, the Alternative Hypothesis $\left(\mathrm{H}_{1}\right)$ which explained that there was a positive and significant correlation between vocabulary mastery and reading comprehension at the second grade of SMP Negeri 1 Kolaka was accepted. The coefficient correlation between variables was 0.705 . It means that vocabulary mastery had an strong correlation with students reading comprehension. It's on 0.705 on the range of $0,60-0,799$. In similar, it could be said that vocabulary mastery and reading comprehension have a relationship one to another.

The result of this research showed that there was positive and significant correlation between students' vocabulary mastery and reading comprehension. It means that if their vocabulary mastery is high, their reading comprehension will be also high and if their vocabulary mastery is low, their reading comprehension will being also low. This research concluded that vocabulary mastery is contributive in helping the students to comprehend the texts. Therefore, the students' vocabulary mastery is contributive in their reading comprehension (Kirana, 2014). In the other word vocabulary mastery supports students' reading comprehension since it makes them easier in comprehending many texts.

Furthermore, this positive correlation was support by the result of data calculated, that is $r_{\text {count }}=0.705$, it was bigger than $r$ table with total participant 26 students and significant level 5\%. It showed the point 0.388 . The students vocabulary had an closed relationship with their reading comprehension, they were able to understand the text more if they have mastered of vocabulary and vocabulary also provide useful contributed in their reading comprehension, if their master of vocabulary they will comprehend the texts better.

Based on the explanation, alternative hypothesis was accepted and null hypothesis was rejected. The researcher proved that there was significant and positive correlation between vocabulary mastery and reading comprehension at the second grade of SMP Negeri 1 Kolaka.

\section{CONCLUSIONS, IMPLICATION, AND SUGGESTIONS}

Based on the finding and discussion, it could be concluded that there was any correlation between students' vocabulary mastery and reading comprehension at the second grade of SMP Negeri 1 Kolaka. From the result of analysis 
descriptive statistic of vocabulary and reading comprehension was good. It could be seen from the computation in which the mean score of the students' vocabulary mastery was 72.30 and mean score of students' reading comprehension was 67.11, when it is consulted the table of category level presented the score is good categorized. The coefficient correlation between students' vocabulary mastery and reading comprehension was 0.705 , it means that coefficient correlation was strong correlation. Based on the result, it could be synthesized that hypothesis is $\rho \neq 0$ or $\mathrm{r}_{\mathrm{xy}}$ was bigger that $\mathrm{rt}$. So $\mathrm{H} 0$ is rejected and $\mathrm{H} 1$ is accepted.

In addition, vocabulary mastery helped the students to comprehend the text. To solve the problem in comprehending the text the students should master vocabulary. Have a good vocabulary can help students in school work easier especially in reading test. This finding support by Timasela in Nur Awaluddin (2016) said that the students who have many vocabularies can explain and present ideas in specific purposes. On the other hand, the researcher concludes that vocabulary mastery has a significant correlation with reading comprehension at the second grade of SMP Negeri 1 Kolaka in the academic year 2017/2018.

Based on the result of the research, some suggestions which hopefully give valuable and useful contribution for the teachers and the next researchers, the English teacher should be a good motivator and support their interest in learning to help students' to improve their vocabulary mastery because it has big influence language skill especially reading. For next researchers, the researcher suggested to conduct a research in a great population or more sample to gain better result. 


\section{REFERENCES}

Ali, Muhammad. 2004. Proses Belajar Mengajar. Bandung: Sinar Baru Algenisido.

Alek, Achmad. 2010. Bahasa Indonesia untuk Perguruan Tinggi. Jakarta: Kencana.

Anastasia, Anne. 2008. Field of Applied Psychology, Alih Bahasa Aryantini Siswohardjono. Jakarta: CV. Rajawali

Arham, M., Akrab, A.H. (2018), Delving into Delving into Content Lecturers' Teaching Capability in Content Language Integrated Learning (CLIL) at an Indonesian University, Asian ESP Journal, Vol. 14 No. 7.2 (2018).

Arikunto, Suharsimi. 2010. Prossedur Penelitian Suatu Pendekatan Praktik, Jakarta: PT. Rineka Cipta

Armbuster. 2002. Reading Instruction and Assessment. Understanding the IRA Standard. Boston: A Pearson Education Company

Awaluddin, Nur. 2016. Correlation Between Students' Vocabulary Mastery and Reading Comprehension at the Second grade of SMP Negeri 3 Tanggetada. Kolaka. USN kolaka

Bond, Pinker. and Wasson. 1979. Reading: Insights and Approaches. Singapore: University Press for SEAMEO Regional English language Center

Brown, H.D. 2000. Principles of Language Learning and Teaching. New York: Addison Wesley Longman, Inc.

Cohen. 2007. Research Method in Education. New York: Routledge.

Dale I., and Chall. 2009. Nonparametric Statistics for Non-Statistician.

Dalman. 2011. Keterampilan Membaca, Penerbit UM Lampung Press, Bandar Lampung

Decarrico, J. S. 2001. Vocabulary Learning and Teaching. In CelceMurcia,M)Ed). Teaching English as a Second and Foreign Language. Boston: Heinle \& Heinle

Eskey. 1986. Theoretical Foundation in Teaching Second Language Reading for Academic Purpose. California: Wesley Publishing Company. 
Fanny. 2012. Pengertian Membaca Menurut Beberapa Ahli.Tersedia [Online].http://chaerulhatami.blogspot.com/2011/07/penertian-membacamenurut-beberapa.html.

Farr. 2013. Keterampilan Membaca. Jakarta: Raya Grafindo Persada. http://rimaputri13.blogspot.co.id/2016/10/definisi-keterampilan-membaca$\underline{\text { menurut.html }}$

Fitriana. 2011. A Correlation Learning Motivation, Vocabulary Mastery, and reading competence. Solo: Sebelas Maret University

Harmer, Jeremy. The Practice of English Language Teaching, New York: Longman, 2001

Hart, B., Risley, T.R. "The Early Catastrophe:The 30 Million Word Gap by Age 3"(2003,spring).AmericanEducator,pp.49.http://www.aft.org//sites/default/ files/periodicals/TheEarlyCatastrophe.pdf

Hadjar, Ibnu. 2010. Dasar-dasar Metodologi Penelitian Kuantitatif dalam Pendidikan, Jakarta : Raja Grafindo Persada

Iskandar. 2008. Metodologi Penelitian Pendidikan dan Sosial (Kuantitatif dan Kualitatif). Jakarta: GP Press

Jamaris., Fahrudin 2005. Peningkatan Penguasaan Kosakata Bahasa Inggris Melalui Permainan. Vol 3. NO.2

Klein. 2009. Project-Based Learning: Inspiring Middle School Student to Engage in Deep and Active Learning . New York: NYC Departement of Education

K.,Judy. 2007. Montgomery's book: The Bridge of Vocabulary: Evidence Based Activities for Academic Success (NCS Pearson Inc)

Kridalaksana. 1982. Kamus linguistic, Edisi ketiga, Jakarta: PT. Gramedia Pustaka Utama

L, Christensen, Johnson B. (2012). Educational Research 4th Ed.: Quantitative, qualitative, and mix-methods approaches. California: SAGE Publication

Klingner. 2007. Teaching Reading comprehension to sedunt. www.lontar.ui.ac.id/file?file=digital/128747-T 26633

M. Jain, Pravin., Dr. M.R. Patel https://www.englishindo.com/2011/06/types-ofreading.html 
Moleong,j, Lexy. 2006. Metodologi Penelitian Kualitatif. Bandung: PT. Remaja Rosdakarya. Muchammad Abdulloh/pengertian-kosakata-menurut-paraahli.html.

Nation., Paul. " Teaching Vocabulary" Asian EFL Journal, Victoria University of Wellington: New Zealand.(1995)

NCS Pearson Inc. 2007. The following information was based on information from Judy K. Montgomery's book: The Bridge of Vocabulary: Evidence Based Activities for Academic Success

Renandya.,Richards. 2002. Methodology in language teaching: anthology of current practice.

Richard.(2003). Approaches and Method in Language Teaching. Cambirdge (UK): Cambirdge University Press

Ro'iyal, Irwan. (2010). The Correlation Between Students' Vocabulary Mastery and Reading Comprehension at the Second Semester of English Department of Syarif Hidayatullah State Islamic Jakarta. Indonesia: Jakarta

Sadhono, Kundharu dan St. Y. Slamet. (2014). Pembelajaran Berahasa Indonesia:Teori dan Aplikasi edisi 2. Yogyakarta: Graha Ilmu.

Sakina, Putri Nurus.,Desi Surlitasari Dewi, and Aulia Putri. "The Correlation between Cognitive Styles and Student's Reading Comprehension” Jurnal anglo-saxon, vol.VIII.no1. (2017)

Smith.2005.https://mrrabbitmymvp.blogspot.co.id/2013/11/pengertian-reading menurut -para-ahli.html

Soejdjito. 2009. Kosakata Bahasa Indonesia. Jakarta: Gramedia Pustaka Utama.

Stahl.,Nagy 2005.http://repository.usu.ac.id

Sugiono. 2005. Metode Penelitian Administrasi, Bandung: Alpabeta

Sugiyono. 2010. Statistika untuk penelitian. Bandung : Alfabeta

Sugiyono. 2008. Metode Penelitian Kuantitatif dan Kualitatif. Bandung: CV.Alfabeta

Suharsimi. 2002. Prosedur Penelitian Suatu Pendekatan Praktek, Jakarta: PT. RinekaCipta 
Sugiono. 2013. "Metode Penelitian Kuantitatif, Kualitatif, Dan Kombinasi (Mixed Methods)”, Edisi Keempat, Bandung : ALFABETA.

Suharsimi. 2004. Manajemen Penelitian. Jakarta. Rineka Cipta.

Suharsimi,Arikunto. 2010. Prosedur Penelitian Suatu Pendekatan Praktek Jakarta:PT. Rineka Cipta.

Soedjito. 2009. Kosakata Bahasa Indonesia. Jakarta: Gramedia Pustaka Utama.

Sudjana. 2005. Metode Statistika: Bandung

Ur,Penny (2007). A Course in language Teaching, Practice and Theory Cambirdge (UK): Cambirdge University Press

Wahyuningsih., lilik. Artikel Skripsi Universitas Nusantara PGRI

Kediri.11.1.01.08.0107, simki.unpkediri.ac.id 